\title{
The Use of E-payment Products and their Impact on Currency-in-Circulation in Nigeria
}

\author{
${ }^{1}$ Kanu Success Ikechi, ${ }^{2}$ Eke Karen Chinonso, ${ }^{3}$ Nwadiubu, Anthony, \\ ${ }^{4}$ Ikechukwu Robert Eze \\ 1,3 Faculty of Social and Management Sciences, Eastern Palm University, Ogboko Ideato, \\ P.M.B 6, Orlu Imo State. Nigeria. \\ 2,4 Department of Management Technology, School of Management Technology, Federal \\ University of Technology, PMB 1526, Owerri, Imo state. Nigeria
}

\begin{abstract}
This study is set to ascertain the relationship between the use of e-payment products and the value of currency in circulation in Nigeria. An ex-post facto research design was adopted in the investigation. A least square regression analysis was carried out on a timeseries data. The objective was to ascertain relationships between the variables, whether positive or negative and to determine its significance. The outcome of the study indicates that only REMITA and WEBPAY have an inverse but significant negative relationship with currency in circulation in Nigeria. At the same time, the use of ATM and POS maintained a positive and significant relationship. This isn't surprising considering ATM and POS machines are verified sources of cash withdrawals in Nigeria. Presently, due to the relatively low use of e-payment products, their influence on monetary policy has been insignificant. The Central bank of Nigeria has not recorded a decrease in currency in circulation followed by an increase in the use of epayment products; instead, it is recorded that between 2009 and 2018, the value of currency in circulation grew by about $97.18 \%$. It is important to stress the fact that any innovation takes time to mature and become accepted in the market. It might be too soon to complain. We ought to expect that in the future, e-money products could be made more acceptable as regular payment instruments. Following this, their influence on monetary policy could be increased. This depends on the extent to which it will substitute the currency in circulation. This means that a developing nation like Nigeria needs to monitor the trend of development of e-money on the market and the increasing degree of use by institutions and clients. Lastly, the regulatory authorities need to develop the capacity to manage an e-money driven economy more closely and more carefully.
\end{abstract}

Keywords: E-payment products, Currency in circulation, E-money, Monetary policy

\section{Introduction}

"Electronic money is expected to replace physical cash, if not all, small-value payments continue to evoke considerable interest, both among the public and the various regulatory authorities." (Papadopoulos, 2007). The Central Bank of Nigeria (CBN) took the initiative in 2011 to launch the cashless policy program. The objective was to achieve Nigeria's vision 2020 goal of pertaining to the top 20 economies of the world. The essence of this program was to reduce the volume of cash in circulation in Nigeria while encouraging the use of electronic-based systems or e-payment systems to carry out the transactions. (CBN, 2012).

Implementation of the cashless policy raised a lot of concerns about the reliability of the epayment systems available at the time and its ability to sustain transactions as expected by the apex bank. In addition to the existing e-payment platforms, the CBN introduced the Nigerian Interbank Settlement System (NIBSS). Two platforms run on the NIBSS; NIBSS Electronic 
Funds Transfer (NEFT) and NIBSS Instant Payment (NIP). The introduction of additional platforms and a percentage charge for cash deposit and withdrawals, over stipulated benchmarks of $\$ 150,000.00$ for individuals and $\$ 3,000,000$ for corporate bodies, led to a significant increase in the e-payment transactions (Okifo and Igbunu, 2015).

Since the implementation of the cashless policy in Nigeria, there has been a substantial improvement in the e-payment infrastructure reliability. The introduction of some new electronic payment platforms which have subsequently led to a significant increase in the use of e-payment systems and the growth in transactions via the various e-payment systems (Ikpefan, Akpan, Osuma, Evbuomwan, \& Ndigwe, 2018). E-payment is therefore seen as an integral aspect of a cashless economy. E-payment is expected to have a significant negative relationship with cash in circulation; as the use of e-payment products increase, cash-in-circulation reduces. The logic being that the more the transactions are carried out electronically, the less physical cash in circulation will be involved (Eze and Nwankwo, 2012).

Surprisingly, in February 2020, the current CBN Governor, Godwin Emefiele, in an interview, said that cashless policy will be re-implemented in April 2020 because there is still a high volume of cash in circulation. This is evidenced by the consistent increase in the number of bills printed by the CBN each year (Ahon, 2020; Paul, 2019). The circumstance surrounding a proposed reimplementation of the cashless policy by the apex bank gave rise to this research. Thus, the study aims to assess if there is a significant relationship between the value of e-payment transactions and the amount of cash-in circulation in Nigeria.

\subsection{Problem Statement}

Nigeria's economy was predominantly cash-based, yet there have been encouraging indications of a cashless drive with the slow adoption of e-payment channels. According to figures from the Nigerian Interbank Settlement System (NIBSS), in 2018, NIBSS recorded 729.4 million instant payment exchanges valued at $\$ 80.4$ trillion (\$223 billion) compared to 370.9 million transactions in 2017 with a value of 56.2 trillion ( $\$ 156$ billion). This indicates a $96 \%$ increase in volume and a $43 \%$ increase in the number of instant payment exchanges. Interestingly, the average everyday usage increased by $96 \%$ from 1.016 million in 2017 to 2million in 2018 .

Strangely enough, an increase in the use of e-payment channels does not seem to have translated to a reduction in the use of cash. Contrarily, the measure of cash in circulation has increased, as depicted in figure 1 below:

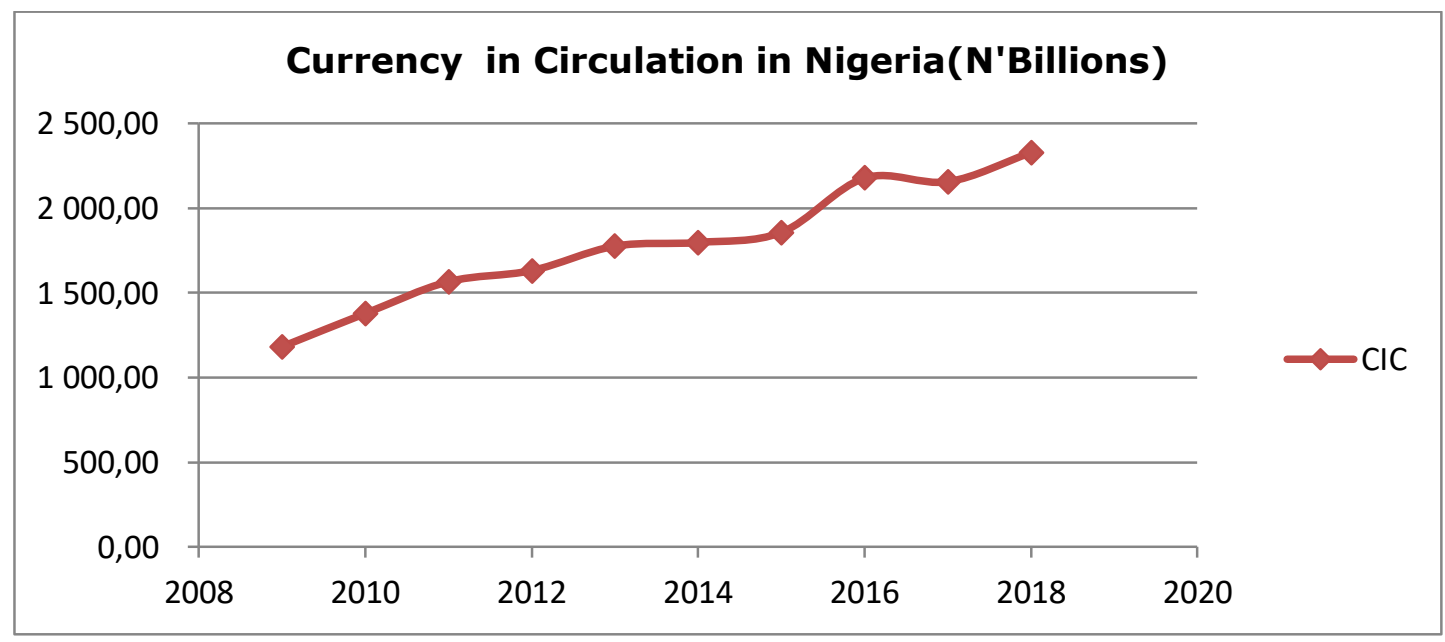

Figure 1: Currency in Circulation in Nigeria

Source: Data were culled from the 2018 CBN Annual report. 
Kanu Success Ikechi, Eke Karen Chinonso, Nwadiubu, Anthony, Ikechukwu Robert Eze The Use of E-payment Products and their Impact on Currency-in-Circulation in Nigeria

The cost of printing of Naira notes are also rising. According to the 2018 yearly report of the Central Bank of Nigeria (CBN), the apex bank procured about 3.35 billion banknotes in 2018, which is a $25.3 \%$ increase compared to 2.67 billion in 2017 . An extra expense of 14.52 billion (\$38.6 million) was incurred as the cost of production went up from $\$ 49.5$ billion ( $\$ 136.6$ million) in 2017 to $\$ 64.04$ billion ( $\$ 176.8$ million) in 2018 . This scenario is aptly captured in figure 2 below:

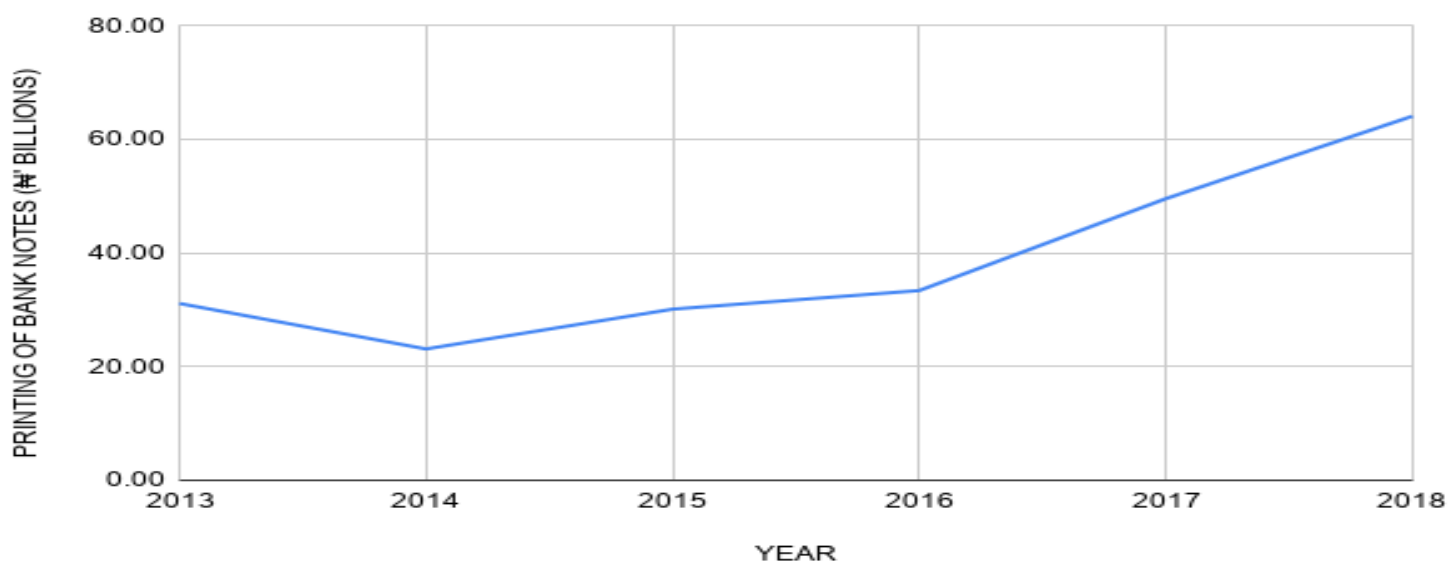

Figure 2: Cost of printing of Bank Notes (N' Billions)

Source: Figures were culled from 2017 and 2018 CBN Annual Reports

There have likewise been significant increments in the expense of distributing currency. This went up from $\$ 4.1$ billion in 2017 to $\$ 5.7$ billion in 2018, while currency disposal increased from \#594 million to N662 million. However, since the implementation of the cashless policy directives, Nigeria has witnessed a continuous increase in the variants and usage of electronic payments. Table 1 below shows the growth path of e-payment transactions for the period 2017 to 2018 .

Table 1: Value of E-Payment Transactions for the period 2017-2018

\begin{tabular}{|c|l|l|l|l|}
\hline & $\begin{array}{c}\text { E-payment } \\
\text { Channels } \\
\text { / Cheques }\end{array}$ & $\begin{array}{c}\text { Year 2017 } \\
\text { (N' } \\
\text { Billions) }\end{array}$ & $\begin{array}{c}\text { Year 2018 } \\
\text { (N' Billions) }\end{array}$ & $\begin{array}{c}\text { Percentage } \\
\text { Increase/ } \\
\text { (decrease) }\end{array}$ \\
\hline 1 & RTGS & 418645.10 & $383,960.10$ & $(8.28)$ \\
\hline 2 & ATM & 6437.59 & 6480.09 & 0.66 \\
\hline 3 & $\begin{array}{l}\text { CENTRAL } \\
\text { PAY }\end{array}$ & 4.99 & 8.10 & 62.32 \\
\hline 4 & E-bills pay & 550.75 & 500.21 & $(9.18)$ \\
\hline 5 & M-Cash & 0.62 & 1.20 & 93.55 \\
\hline 6 & Mobile Pay & 1101.99 & 1830.70 & 66.13 \\
\hline 7 & NAPS & 4960.35 & 6091.95 & 22.81 \\
\hline 8 & NEFT & 14946.46 & 11030.96 & $(26.2)$ \\
\hline 9 & NIP & 56165.67 & 80423.03 & 43.19 \\
\hline 10 & POS & 1409.81 & 2383.11 & 69.04 \\
\hline 11 & REMITTA & 13529.50 & 18495.99 & 36.71 \\
\hline 12 & WEBPAY & 184.60 & 404.60 & 119.18 \\
\hline
\end{tabular}


Despite increases in the use of e-payment channels, there has also been a steady increase in the volume and value of currency in circulation. There seem to be policy inconsistencies, contradictions and, consequently, confusion over the effects of the implementation of a cashless policy on the Nigerian economy as this situation violates the expectations upon which the cashless policy was adopted. It is expected that, as the economy boosts the use of electronic channels and payments, there should be a gradual decline in the amount of physical currency in circulation. It is also expected that this decrease will rid the Nigerian nation from the enormous cost of printing Naira notes and a consequent reduction in the cost of distributing the same. This research is, therefore, set to evaluate the impact of the use of e- payment products on cash in circulation in Nigeria.

\subsection{Aim of the Study}

Centrally, the study is intended to ascertain the impact of the use of e- payment products on the amount of physical cash in circulation in Nigeria. We will examine the seeming mismatch between the increased usage of e- payment products as against an upsurge in the volume and value of cash in circulation in Nigeria, which typically would not be the case if there is a synchronization of policy outcomes by the apex bank. Presently, there are about 12 variants of e- payment channels in Nigeria, as listed in table 1 above, but some of them are still at their formative stages. We intend to review the impact of 8 out of the 12 variants of e-payment channels that are currently operational in Nigeria. Thus the specific objectives of this study will be to determine the:

b) Effects of Real-time Gross Settlement (RTGS) on the level of currency in circulation in Nigeria.

c) Effects of NIBSS Instant Payments (NIP) on the level of currency in circulation in Nigeria

d) Influence of National Electronic Fund Transfer (NEFT) on the level of cash in circulation in Nigeria

e) Influence of Mobile payment (MOPAY) on the level of currency in circulation in Nigeria

f) Impact of Automated Teller Machines (ATM) on the level of currency in circulation in Nigeria

g) Impact of REMITA on the level of currency in circulation in Nigeria

h) Effects of the use of Point of Sale terminal (POS) on the level of currency in circulation in Nigeria.

i) Influence of Web pay (WEBPAY) on the level of currency in circulation in Nigeria.

\subsection{Research Questions}

Having stated the above objectives, the following research questions are therefore considered relevant for the investigation.

1) What is the nature of the relationship between e-payment products and currency in circulation in Nigeria?

2) To what extent has Real-time Gross Settlement (RTGS) affected the level of currency in circulation in Nigeria?

3) What is the level of influence of NIBSS Instant Payments (NIP) on the currency in circulation in Nigeria?

4) To what extent has the National Electronic Fund Transfer (NEFT) affected the level of currency in circulation in Nigeria?

5) What is the nature of the relationship between Mobile pay (MOPAY) and the level of currency in circulation in Nigeria?

6) To what extent has the use of Automated Teller Machines (ATM) affected the level of currency in circulation in Nigeria?

7) What is the level of influence of REMITA on currency in circulation in Nigeria?

8) To what extent has the Point of Sale terminal (POS) affected the level of currency in circulation in Nigeria?

9) To what extent has the web pay (WEBPAY) affected the level of currency in circulation in Nigeria? 
Kanu Success Ikechi, Eke Karen Chinonso, Nwadiubu, Anthony, Ikechukwu Robert Eze The Use of E-payment Products and their Impact on Currency-in-Circulation in Nigeria

\subsection{Hypotheses of the Study}

Ho $_{1}$ : There is no significant relationship between the use of e-payment products and currency in circulation in Nigeria.

$\mathrm{Ho}_{2}$ : There is no causal relationship between the use of e-payment products and currency in circulation in Nigeria.

\subsection{Significance of the Study}

This study is significant, given it will examine the relationship between the use of e-payment products and the amount of currency in circulation in Nigeria. We will attempt to identify currently available e-payment product options and their impact on the level of currency in circulation in Nigeria.

- The possible influence of electronic money on monetary policy is a topic of professional interest. The study could assist policymakers in ascertaining if there are ways to ensure effectiveness in the re-implementation of the cashless policy or if they should explore other policy options.

- It may provide evidence for the debates on the need for the continued printing of naira notes when e-payment channels have been adequately harnessed to tackle cash related transactions.

- It will set forth arguments on whether more can be done by the government to reduce demand for cash.

- It will likewise serve as reference materials for the future and further works in this area, providing a reason for further comparative studies on both the developed and less developed economies.

- Finally, it will integrate the existing literature on the subject matter

- It will likewise help to educate the general public, private sectors, economists and students alike

\subsection{Scope of the Study}

The effect of e-payment products on the currency in circulation in Nigeria is a relatively new topic. The investigation is limited to the Nigerian context, according to data for the ten years from 2009-2018.

\section{Literature Review}

The conceptual framework of this study is based on the variables under consideration. These are the following:

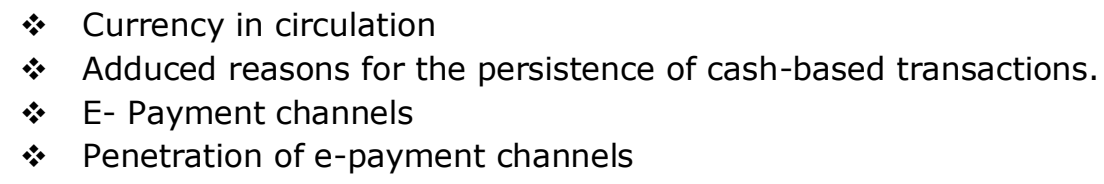

A brief discussion is presented below:

\subsubsection{Currency in Circulation}

Currency in circulation can be described as the physical cash in the hands of individuals with which they transact business among themselves and corporations. Cash in circulation in Nigeria refers to the total bills issued by the CBN that is not stored in the accounts of any financial institution. Currency in circulation can also be thought of as "currency in hand" as it is used to transact business across all sectors of the country's economy. Monetary authorities monitor cash in circulation because it represents the amount of cash available to fund short term spending, which is a significant component of a country's GDP (Ikpefan et al., 2018). 
The Central Bank of Nigeria (CBN) deals with a number of monetary policy decisions, one of which is the level of money supply in the Nigerian economy. Money supply may be divided into two types: narrow money and broad money. According to the CBN, narrow money (M1) includes currency in circulation and commercial banks' current account deposits, while broad money describes the total volume of money supply in the economy (narrow money, savings \& time deposits with banks including foreign currency deposits). While growth in currency in circulation could reflect an increase in the economic activities of a country, it could also cause a surplus of money in the economy, which could result in inflation.

\subsubsection{Adduced Reasons for the Persistence of Cash-Based Transactions}

Over the years, experts have given various reasons why cash transactions will remain the preferred method of transacting business in the retail sector. These reasons include, but are not limited to, the following: Firstly, cash payments are considered cheap as they do not involve any additional infrastructure or charges. Secondly, it is accessible to everybody in society regardless of class, status, race, or gender. Contrary, e-payment options are less inclusive since individuals are required to have a bank account to make transactions. Requesting the bank account leads to leaving out those who do not have access to banks or banking facilities, especially those in the rural areas and technologically illiterate population. Thirdly, cash payments are direct and are not dependent on the approval or disapproval of any intermediaries. Fourthly, we should be mindful of the existence of 'cash ghettos'-a group of people that do not have access to banks, which makes them resort to third parties to carry out transactions on their behalf for a premium in a cashless society. Besides, cash is anonymous; therefore, it protects the privacy of the individuals transacting business; this is both a benefit and a hazard as it offers freedom on the one hand and increased crime on the other (Papadopoulos; 2007).

E-payment transactions will always leave behind an audit trail. Fraudsters are not comfortable with that. They will always prefer the use of raw cash Lastly, the cash needs of government and her expenditure pattern is yet another critical exogenous factor that needs to be considered when we are reviewing the concept of currency in circulation in Nigeria. According to Salami (2017), a well-regarded member of the Monetary Policy Committee of the CBN, "the apex bank may have been providing a "secret stash" service to the federal government". He quoted insights that showed that the CBN might have been printing money to finance the government's spending. The reason for this is, of course, apparent-Nigeria's government has not been able to recover in any meaningful manner from the collapse in oil prices. This, in no small extent, exerts an enormous pressure on the measure of currency in circulation in Nigeria

\subsubsection{E-Payment Channels}

Presently, there are about 12 options for e- payment in Nigeria. They are briefly discussed below:

\subsubsection{E-Bills}

An e- bill (electronic bill) refers to an electronic version of a paper bill visible and applicable in an online setting. It is usually delivered to the website of the company with which the business was transacted. This inFcludes banks, utility companies, credit unions, etc.

Electronic bills are environment-friendly, secure, and very convenient. They can be filed online, set-up for regular payment and securely paid online. E-bills payment is usually received within 2 to 7 days, depending on the payment method.

\subsubsection{M-Cash}

$M$-cash is an innovative solution designed to increase financial inclusion in Nigeria. It offers epayment benefits to SMEs and individuals at the bottom of the pyramid, enables low-value retail payments, aids in the development of e-payment by providing accessible electronic channels to a neglected range of users, etc. 
M-cash is a simple payment solution that allows retail merchants payment of goods and via the use of a mobile phone.

Operating an M-cash is quite simple. The payer's phone number is used to retrieve his/her bank(s) and account numbers when a string is dialed, or a push service is initiated. The M-cash USSD session is zero-rated and will work on any mobile phone, whether its feature or Smartphone. $\mathrm{M}$-cash is used to facilitate low-value retail payments and to provide accessible payment channels to enhance financial inclusion. The target markets of $\mathrm{M}$-cash are retail merchants, Small and Medium Scale Enterprises and Financial Institutions.

A unique value proposition of $\mathrm{M}$-cash is that it is already available in all the existing banks in Nigeria and on all 4 Telecoms Operators in Nigeria; other institutions can integrate their unique USSD codes to the M-cash payment gateway

\subsubsection{Remita}

Remita is a Central Bank of Nigeria (CBN) licensed platform. It is mainly used by the Federal Government of Nigeria (FGN) as a platform upon which government funds can be received and government payments made. Nigerian banks, merchant, commercial and microfinance, have all synchronized their systems to be able to interface with remita to help forward government money immediately after they receive it to avoid being fined.

Remita has been instrumental to the achievement of the Treasury Single Account (TSA) implemented by the Nigerian government. It helps users make online payments directly to the government account in the CBN via the users' bank using any electronic device.

Remita's success in Nigeria has led it to be considered one of the most preferred payment platforms in Africa.

\subsubsection{Mobile Payment}

Mobile payment (likewise referred to as mobile money or mobile wallet) generally refers to any payment service operated under financial regulations and performed using any mobile device. The original patent exclusively defined as the "Mobile Payment System" was filed in 2000. Mobile Money is a service whereby customers use their mobile device to send and receive monetary value, i.e., to transfer money electronically from one person to the next using a mobile phone as Mobile Wallet". MTN offers mobile money as a team with GT-Bank. It is one of numerous mobile money services that were launched in Nigeria. Mobile money is a service that allows merchants to receive payments and services using MTN Mobile Money. It is, however, not limited to merchants only, as customers, too, can use it to pay for the same goods and services to merchants.

Some of the significant benefits of Mobile Payments include Integrated and increase incentive programs, the ability to offer credit card payments and the tracking of customer trends and inventory. Other benefits include an increased speed of checking customers and savings on credit card fees.

\subsubsection{Central Pay}

Central pay is a record number-based online real-time Credit Transfer product. It enables customers to make payments by leveraging the security provided by banks and enables banks to deliver electronic bills payment services through payment Channels, for example, Internet Banking, Mobile Banking, Kiosk, etc.

\subsubsection{Point-of-Sale Terminal}

The merchant's bank issues point of Sale (POS) terminals on the merchant's request. The merchants use them in different domains to conduct business with their customers. Customers 
slot their electronic cards into or through the POS in order to make payments for purchases or services instead of using physical cash. Since the POS terminals are typically online real-time, the customer's financial balance is expected to be debited immediately in the value of purchases made.

Point of Sale (POS) terminals additionally allow merchants access to card payments available to be purchased of other products and services like airtime recharge cards, charge payments (including service charges), lottery tickets, etc.

\subsubsection{NIP}

NIBSS Instant Payments (NIP) is a record number based online-real-time Inter-Bank payment arrangement. It was developed NIBSS (Nigerian Interbank Settlement Scheme) in 2011. It is the preferred fund transfer platform in the Nigerian financial industry as it guarantees instant value to the beneficiary. With this channel, users can transfer funds to any Nigerian bank account instantly. However, it restricts transfers to not more than two people at a time. Mass transfer can be made through NEFT option.

\subsubsection{NEFT}

NEFT essentially means National Electronic Fund Transfer, which is a nationwide electronic payment system allowing the rapid interbank transfer of funds. NEFT is used for mass transfer of funds to numerous recipients at once. However, NIP especially designed for money transfer among two people at the same time.

The exchanges between banks are processed and settled in batches of one hour on netting off basis. Hence, the time to transfer the assets can range between 1-2 days.

NEFT and RTGS services are unavailable on weekends and bank holidays, while NIPS services can be availed round the clock. Also, NEFT transfers funds in timed batches, while RTGS and NIPS are real-time transfer modes. NEFT and NIPS have no minimum value, while RTGS has a minimum fund value.

\subsubsection{NIBBS Automated Payment Services}

NIBSS Automated Payment Services (NAPS) is an integrated multi-bank e-Payment, eCollection and Payroll and Bulk Payment Platform. It is designed for the instant processing of finance, pension, personnel records and execution of assets transfer, direct debit, collections, schedule delivery and payment instructions. Nigeria Inter-Bank Settlement System Plc (NIBSS) aims to strengthen and enhance its mass payment processing NIBSS Electronic Funds Transfer (NEFT) offering, to deliver improved operational efficiencies and increased usefulness to its customers through the reception and deployment of the NAPS Platform for inter-bank exchanges

\subsubsection{Automated Teller Machines (ATM)}

An ATM is a machine mounted into the wall of a bank or other building, allowing people to withdraw money from their ledger by using a special card called an ATM card. ATM is an abbreviation for 'automated teller machine. They are used more frequently to make a variety of online payments like service charges, cable memberships, airtime, and information recharges etc. Customers are consistently advised by their banks to keep their ATM cards safe and never to divulge their ATM card pins

\subsubsection{RTGS: Real-Time Gross Settlements:}

This is a transfer method used by Nigerian banks to move sums above N10 million for a single beneficiary. Real-time gross settlement systems are specialist transfer support systems where the transfer of money or securities takes place from one bank to some other bank on a "realtime" and a "gross" premise. Real-time gross settlement systems are commonly used for highvalue exchanges that require and receive immediate clearing. The fundamental difference between RTGS and NEFT is that while RTGS is based on gross settlement, NEFT is based on netsettlement 
Kanu Success Ikechi, Eke Karen Chinonso, Nwadiubu, Anthony, Ikechukwu Robert Eze

The Use of E-payment Products and their Impact on Currency-in-Circulation in Nigeria

\subsubsection{Web Pay}

Web pay is an online service that manages the transfer of assets from a customer to the ecommerce site merchant. The money may come from a prepaid record or credit card stored in a digital wallet in the user's device or stored in the service's server or center.

\subsubsection{Explaining the Low Penetration of E-Payment Channels}

E-money can substitute currency in circulation, which is a part of the monetary aggregates from the balance sheet of central banks (Papadopoulos; 2007), but we are yet to see that in Nigeria effectively. This is not to say that electronic money has failed. No. It may be too early to say that, albeit the available evidence contradicts some of the most ambitious predictions about the imminent 'end of the cash era.' There are some fundamental reasons for the low penetration of e-payment products in Nigeria. This includes the fact that:

* E-money is more expensive to transact business because of the bank and other charges, although this has recently been reviewed in an attempt to lower costs.

* E-money is not so user friendly when compared to cash.

* E-money is at a disadvantage as it is competing in an environment where cash has had a monopoly for over 100 years.

* The hope that the development of a widespread network of terminals and a broad base of emoney users will lead to economies of scale, lowering the average fixed costs, did not materialize. Maybe this could change if the volumes of transaction and the consumer basis increase further, judging by current trends, the necessary amounts may never be reached in most e-money projects in Nigeria.

* The expenses and the benefits for cash just as for electronic money are not equally distributed. The fee for issuing cash is paid by the state and financed by tax assessment. The vast majority of the e-money infrastructure is funded by the issuer, which in turn charges the user for this payment instrument.

* Cash is a public good, while electronic money is a service usually connected to a bank account and the bank can and does exclude people from that service.

* Consumers keeping funds in cash or a pre-charged card bare the same opportunity cost. The issuing institutions can benefit from 'floating' on balance held in e-money. In the case of cash this float is the seigniorage that goes to the state. The 'float' on cash is more beneficial to the country.

* Under the e-money platform, there are movement costs from one system of payments to the other, costs that include investment in new infrastructure just as time and effort of familiarizing with the new system. These may become a deterrent to change and may even lead to a lock in the norm

* E-payment merchants are often reluctant to undertake the investments necessary for accepting e-money.

* It seems as if the expectations about the impact of electronic money in the monetary system were hugely inflated. E-money may have looked like a good idea a few years ago, but today cash has proved more resilient than initially thought.

Conclusively, it could be said that the monetary system is in the process of change under the influence of new technologies. It is conceivable that the road to a more efficient payment system and even to a cashless society may not necessarily pass through the establishment of electronic money. (Papadopoulos, 2007).

\subsection{Theoretical Framework}

\subsubsection{The concept of Money Supply}

Money supply can be defined as those assets which represent immediate purchasing power in the economy and hence work as a medium of exchange in Nigeria. The narrow money supply $\left(M_{1}\right)$ is defined as a currency outside banks in addition to demand deposits of commercial banks 
Kanu Success Ikechi, Eke Karen Chinonso, Nwadiubu, Anthony, Ikechukwu Robert Eze

The Use of E-payment Products and their Impact on Currency-in-Circulation in Nigeria

plus domestic deposits with the Central bank, less federal government's deposits at commercial banks (Anyanwu and Oaikhenan, 1995)

In simple terms, $\mathrm{M}_{1}$ is defined as $\mathrm{M}_{1}=\mathrm{C}+\mathrm{D}$

Where $M_{1}=$ Narrow money supply.

$\mathrm{C}=$ Currency outside banks

$\mathrm{D}=$ Demand deposits

Anyanwu and Oaikhenan (1995) opined that Broad money or M2 is the appropriate definition of money in Nigeria. Broad money here includes narrow money assets and what's more those assets which have the nature of liquidity. They can be rapidly and readily converted to cash and the conversion is achieved with little or no loss in terms of either interest penalty or capital loss through forced sale. In the Nigerian context, broad money (M2) is defined as M1 in addition to semi money. Quasi or semi money, as used here, is defined as the entirety of savings and time deposits with the commercial bank. Along these lines, M2 is symbolically shown as:

$M_{2}=C+D+T+S$

Where:

$\mathrm{M}_{2}=$ Broad money

$\mathrm{C}=$ Currency in circulation

$\mathrm{D}=$ Demand deposit

T= Time deposits

$S=$ Savings deposits

Time deposits as used here are those obligations of the bank on which interest is paid and which at least potentially or formally can be made available to the depositor after some days and notice.

We also have the nominal and real money supply. The nominal money supply is measured in monetary units and it is assumed that the monetary authorities control only the nominal amount of money which will be available in an economy. On the other hand, the real money supply is measured in units of constant purchasing power, i.e., the purchasing power of the existing money stock.

In any economy, there are some fundamental determinants of the money supply. This includes:

- Total reserves supplied by the central bank: if the total reserves provided by the central bank are high, the money supply will be high.

- Reserve Requirement: If the reserve requirement is high, the money supply will be low.

- Demand for currency: If the non-bank public increases its demand for currency, money will grow.

- Demand for time deposits: If the non-bank open increases its demand for time deposits, money supply increases.

- Demand for excess reserves: If commercial banks demand for excess reserves increases, money supply increases.

- Interest Rates: There is a positive relationship between the money supply and interest rate. That is, the higher the interest rate, the higher the money supply.

- The Bank Rate: If the rate at which commercial banks acquire from the central bank or markdown charges rises, money supply falls (Anyanwu and Oaikhenan, 1995).

\subsection{Empirical Review}

According to Papadopoulos (2007), the introduction of electronic money enhanced the positive thinking for a quick passage to a cashless, even money less society. Nonetheless, the prognoses 
for the elimination of cash have been proved wrong up until now and it is rather electronic money that is struggling for survival.

Popovska-Kamnar (2014) did a study on the use of electronic money and its effect on monetary policy. This researcher opined that e-money is the newest payment instrument. As a part of the new automated payment system (possible future substitute of regular payment), e-money raises the professional interest in its implications on further development of worldwide and networked economy banking capacities. Factual evidence affirms the existence of e-money in the developed countries, which is understandable because of their high technological level and knowledge and the capacity to ingest useful innovations of any kind. Even though electronic money has been in their markets for more than 20 years, its use is still at a deficient level.

Some developing countries are still in the phase of accepting electronic banking. E-money can substitute currency in circulation, which is a part of the monetary aggregates from the balance sheet of central banks. Until further notice, the influence isn't significant - central banks are recording a very low decrease of currency in circulation as a result of an increase of e-money According to John Williams (2016) - president of San Francisco Federal Reserve, in and around the globe, cash of all kinds is growing, not merely dollars. Williams additionally asserted that in 40 of 42 significant economies - from Europe and Asia to Latin America and the United States the growth of cash in circulation outpaced economic development over the most recent ten years.

The above assertions have been corroborated even by the private sector. According to Western Union, the payment transfer giant -Today, $83 \%$ of global transactions are in cash. "We don't believe in a world that will be cashless-Cash will continue to be the bulk of payments ... for the next 50 years, but digital money will grow faster." John Williams (2016) likewise stated that Cash in circulation increased drastically in countries with varying types of distress: $442 \%$ in Mozambique, $413 \%$ in Myanmar, $355 \%$ in Ukraine. In more advanced countries, cash in circulation didn't soar that much; however, it outpaced overall economic development. This includes the United Kingdom, Canada and Japan.

Gillespie (2017) stated that the payment systems have increased in recent years, however, that the amount of American currency in circulation and around the globe has become $87 \%$ over the previous ten years. According to a San Francisco Federal Reserve report, in 2016, \$1.46 trillion worth of US dollars were changing hands all over the world.

A separate New York Federal Reserve study (2017) enthused that in most countries, demand for notes and coins is strong and shows no signs of slowing down."In line with the above observations, the timing of this study is appropriate, considering that, the Central bank of Nigeria seems to be at a crossroad over the implementation of the cashless policy program alongside with its active and pivotal ancillaries - the e-payment channels. It is contradictory that the apex bank, in conjunction with the NIBSS, rolled out new e-payment platforms /products and yet is intensifying efforts at printing and distributing more currency notes in the economy. The seeming mutually exclusive events ought not to maintain the same growth trajectory. As the cashless economy and its ancillaries-the e-payment channels are coming up, and there should be a carefully worked out monetary policy aimed at reducing the value and volume of currency in circulation. That is the essence of this study. Thus, this paper is set to corroborate or refute the prognosis of the earlier cited works on this discussion.

\subsection{Gap in the Literature}

Beyond the routine monetary policy reports, not much attention has been paid to a possible relationship between the use of e- payment products and Currency $\mathrm{n}$ circulation in Nigeria. That is a research hole that this investigation intends to fill. 


\section{Research Methodology}

An ex-post facto research design was adopted in this study. A least square regression analysis was carried out on a time-series data. The objective was to test the relationship between the variables and their significance.

For the analysis of the relationship between e-payment products and currency in circulation in Nigeria, a multiple regression model was adopted. Regression estimates are derived using the ordinary least squares (OLS) method. A Granger causality test was also carried out to ascertain if the use of e-payment products granger causes currency in circulation in Nigeria.

\subsection{Test Statistics}

$\mathrm{F}$ and $\mathrm{T}$-statistics tests are used to ascertain model and variables significance respectively Decision Rule-F test: Reject HO if Fcal>F 0.01, 0.05(v1, v2), otherwise don't reject. Meaning that whenever computed F-proportion is greater than the table value, we accept $\mathrm{H}_{1}$ and reject $\mathrm{H}_{0}$, concluding that the model is significant. This means the model is adequate and is reliable for any analysis drawn from it.

The Student T-test

Decision Rule-T test: If tcal <ttab at a/2 level of significance and $n-k-1$ degree of freedom, accept $\mathrm{HO}$ and don't accept $\mathrm{H} 1$. On the off chance that tcal $>$ ttab at $\mathrm{a} / 2$ level of significance and $\mathrm{n}-\mathrm{k}-1$ degree of freedom; reject $\mathrm{H} 0$ and accept $\mathrm{H} 1$ and conclude that the variable is significant

\subsection{Model Specification}

It is necessary to stress that there are about 12 variants of e-payment platforms operating in Nigeria. We narrowed our research to 8 out of the 12 channels based on the availability and continuity of data and the volume /Amounts involved. The chosen platforms are RTGS, NIP, NEFT, MOPAY, ATM, REMITA, POS and WEBPAY. We thus specify the relationship between the e-payment products and currency in circulation in Nigeria thus:

$\mathrm{CIC}=\mathrm{f}($ RTGS, NIP, NEFT, MOPAY, ATM, REMITA, POS, WEBPAY)

The above mathematical notation is translated into a model thus:

\section{Model 1:}

CIC $=a_{0}+a_{1}$ RTGS $+a_{2}$ NIP $+a_{3}$ NEFT $+a_{4}$ Mopay $+a_{5}$ ATM $+a_{6}$ REMITA $++a_{7}$ POS $+a_{8}$ Webpay $+e$. Eq. 1

Where

CIC represents currency in circulation for the period 2009-2018.

Other e-payment products are represented thus:

RTGS= Real-time Gross Settlement; NIP = NIBSS Instant Payments (NIP)

NEFT = National Electronic Fund Transfer; MOPAY = Mobile payment,

ATM $=$ Automated Teller Machines (ATM); REMITA=REMITA,

P.O.S. =Point of Sale terminal (POS) and WEBPAY = Web pay.

$\mathbf{e}=$. The error term assumed to be normally and independently distributed with zero mean and constant variance, which captures all other explanatory variables in which the relationship between e-payment products and currency in circulation in Nigeria could not captured in the model.

\subsection{Apriori Expectation}

While the use of physical cash is expected to decline, that of e-payment products is expected to increase. 


\section{Data Analysis and Interpretation}

\section{Test of Hypothesis 1}

The analysis and discussions below are based on equation 2 from table 2 parameter estimates CIC $=0.24$ ATM -1.13 MOPAY $-0.002 \mathrm{NEFT}-0.03 \mathrm{NIP}+3.27 \mathrm{POS}-0.09 \mathrm{REMITA}-0.0003 \mathrm{RTGS}-4.11$ WEBPAY. Equation 2

Equation 2 shows that the estimates of REMITA and WEBPAY have a significant negative relationship with currency in circulation (CIC) in Nigeria. More specifically, the estimates of MOPAY, NEFT, NIP, REMITA, RTGS and WEBPAY are negatively related to CIC, which means that they have an inverse relationship to the CIC. The implication is that any unit change in MOPAY, NEFT, NIP, REMITA, RTGS and WEBPAY will result into a $112.9 \%, 0.18 \%, 3.49 \%, 9.2 \%, 0.03 \%$, and $410.8 \%$ decrease in CIC correspondingly short-term. At the same time, the use of ATM and POS maintained a significant positive relationship with CIC in Nigeria, implying that any unit change in ATM and POS will result into a $24.3 \%$ and $326.6 \%$ increase in CIC correspondingly in the short run. This was not surprising seeing that ATM and POS machines are verified sources of cash withdrawal in Nigeria.

\section{Table 2: Ordinary least square estimates}

Dependent Variable: CIC.

Method: Least Squares

Sample: 20092018

Included observations: 10

\begin{tabular}{crrrr}
\hline \hline Variable & Coefficient & Std. Error & t-Statistic & Prob. \\
\hline \hline C & 1353.005 & 28.06115 & 48.21632 & 0.0132 \\
ATM & 0.242849 & 0.018668 & 13.00861 & 0.0488 \\
MOPAY & -1.129035 & 0.775702 & -1.455501 & 0.3832 \\
NEFT & -0.001809 & 0.002842 & -0.636492 & 0.6392 \\
NIP & -0.034873 & 0.009637 & -3.618822 & 0.1716 \\
POS & 3.266098 & 0.481900 & 6.777548 & 0.0933 \\
REMITA & -0.091931 & 0.012980 & -7.082262 & 0.0893 \\
RTGS & -0.000323 & 0.000162 & -1.989152 & 0.2966 \\
WEBPAY & -4.107774 & 0.403684 & -10.17572 & 0.0624 \\
\hline \hline R-squared & 0.999728 & Mean dependent var & 1785.588 \\
Adjusted R-squared & 0.997552 & SD dependent var & 364.7426 \\
SE of regression & 18.04497 & Akaike info criterion & 8.121026 \\
Sum squared resid & 325.6210 & Schwarz criterion & 8.393353 \\
Log-likelihood & -31.60513 & Hannan-Quinncriter. & 7.822284 \\
F-statistic & 459.5100 & Durbin-Watson stat & 2.026149 \\
Prob(F-statistic) & 0.036064 & & & \\
\hline \hline
\end{tabular}

Source: E-views statistical package version 9

The overall model, as shown in Table 2 is statistically significant as the probability value is 0.03 , which is less than $5 \%$. The Durbin Watson statistical value falls within ( 2 and 4 )standard scale; that is, 2.03 confirms the absence of autocorrelation. The coefficient of determination $\left(R^{2}\right)$ value of 0.99 and adjusted R-square of 0.99 indicates that e-payment products can explain currency in circulation by $99 \%$. In comparison, about $1 \%$ of currency in circulation cannot be interpreted as a result of some exogenous factors.

\section{Test of Hypothesis 2}

\section{Causal Effects}

The analysis and discussions below are based on parameter estimates of table 3 : 
Kanu Success Ikechi, Eke Karen Chinonso, Nwadiubu, Anthony, Ikechukwu Robert Eze

The Use of E-payment Products and their Impact on Currency-in-Circulation in Nigeria

Real-time Gross Settlement Scheme (RTGS) granger causes currency in circulation (CIC), while currency in circulation granger causes ATM withdrawals

\section{Table 3}

Pairwise Granger Causality Tests

Date: $04 / 11 / 20$ Time: $21: 14$

Sample: 20092018

Lags: 2

\begin{tabular}{|c|c|c|c|}
\hline Null Hypothesis: & Obs & F-Statistic & Prob. \\
\hline ATM does not Granger Cause CIC & \multirow[t]{2}{*}{8} & 2.32348 & 0.2457 \\
\hline CIC does not Granger Cause ATM & & 88.4026 & 0.0022 \\
\hline MOPAY does not Granger Cause CIC. & \multirow[t]{2}{*}{8} & 4.53293 & 0.1240 \\
\hline CIC does not Granger Cause MOPAY & & 0.41091 & 0.6955 \\
\hline NEFT does not Granger Cause CIC & \multirow[t]{2}{*}{8} & 0.12316 & 0.8884 \\
\hline CIC does not Granger Cause NEFT & & 0.08391 & 0.9216 \\
\hline NIP does not Granger Cause CIC. & \multirow[t]{2}{*}{8} & 5.33762 & 0.1027 \\
\hline CIC does not Granger Cause NIP & & 0.59575 & 0.6055 \\
\hline POS does not Granger Cause CIC. & \multirow[t]{2}{*}{8} & 8.10359 & 0.0617 \\
\hline CIC does not Granger Cause POS & & 1.31765 & 0.3884 \\
\hline RTGS does not Granger Cause CIC. & \multirow[t]{2}{*}{8} & 58.3965 & 0.0040 \\
\hline CIC does not Granger Cause RTGS & & 0.75205 & 0.5436 \\
\hline WEBPAY does not Granger Cause CIC & \multirow[t]{2}{*}{8} & 0.69033 & 0.5667 \\
\hline CIC does not Granger Cause WEBPAY & & 1.02020 & 0.4592 \\
\hline
\end{tabular}

\section{Conclusion and Recommendations}

\subsection{Summary}

The main findings of this investigation are highlighted below:

- The variables MOPAY, NEFT, NIP, REMTA, RTGS and WEBPAY, all have an inverse relationship with currency in circulation, implying that a unit change in any of the variables will bring about a corresponding decrease in the currency in circulation (CIC)

- Out of all six variables having an inverse relationship with currency in circulation, only REMITA and WEBPAY maintained a significant negative correlation with currency in circulation in Nigeria.

- The variables ATM and POS maintained a positive and significant relationship with currency in circulation in Nigeria. This was expected as ATM and POS machines are verified sources of cash withdrawals in Nigeria.

- Real-time Gross Settlement (RTGS) granger causes currency in circulation (CIC), while currency in circulation granger causes ATM withdrawals.

Based on the outcome of the study, our results are in line with the earlier works of Papadopoulos (2007), Popovska-Kamnar(2014) and Gillespie(2017). They found that the influence of e-money does not have any significant impact on monetary policy. The Central bank of Nigeria has not recorded a decrease in currency in circulation caused by an increase in the use of e-payment products. Instead, it is recorded that between 2009 and 2018, the value of currency in circulation grew by about $97.18 \%$. 
Our results are consistent with those of earlier scholars who enthused that the demand for physical cash is solid and provides no indications of a decrease. We conform with Papadopoulos (2007 that prognoses regarding cash elimination were proved wrong until now. It is rather electronic money which is struggling for survival.

\subsection{Conclusion}

The outcome of the study indicates that only REMITA and WEBPAY have an inverse but significant negative relationship with currency in circulation in Nigeria. At the same time, the use of ATM and POS maintained a positive and significant relationship with currency in circulation in Nigeria. Due to the relatively small use of e-payment products, its influence on monetary policy has not have been significant. The Central bank of Nigeria has not recorded a currency in circulation decrease, followed by an increase in the use of e-payment products. Instead, between 2009 and 2018, the value of currency in circulation grew by about $97.18 \%$.

Conclusively, it could be said that the influence of e-money products in Nigeria could be measured by its capacity to substitute currency in circulation. Up until now, due to the relatively low use of e-money, its influence on monetary policy might not have been tremendous. This does not mean that it will remain like that in the near future

\subsection{Recommendations}

E-money transactions are usually undertaken by consumers, small and medium-term organizations. To boost the usage and frequency of e-money products, customized products should be introduced to the government, the public sector, and corporate entities.

Based on the results of our empirical analysis, we conclude that if Nigeria wants to reduce the level of currency in circulation and to enhance the performance of the cashless policy program, it is crucial to increase the usage and volume of those e-payment transactions that maintained an inverse relationship with currency in circulation. Lastly, we should take cognizance of the fact that any innovation takes time to mature and be accepted in the market. It might be too soon to make conclusions. We expect that in the future, e-money products could be made more acceptable as regular payment instruments. Following this, its influence on monetary policy could be increased. This will depend on the extent to which it will substitute the currency in circulation. Developing nations like Nigeria need to screen the trend of development of e-money on the market and the increasing degree of adoption by institutions and clients. Furthermore, the regulatory authorities need to develop the capacity to manage an e-money driven economy more closely and more carefully.

\section{References}

- Ahon, F. (2020). Cashless policy is to cut down the volume of money in circulation.BM

- Anyanwu.J.C and Oikhenan.H.E(1995), Modern Macroeconomic: Theory and Applications in Nigeria; Joannee Educational publishers, Onitsha,Nigeria

- CBN Annual reports (2009) to (2018)

- CBN. (2012). Cashless Nigeria. Retrieved February 28, 2020, from https://www.cbn.gov.ng/cashless/

- CBN(2006)," How does the monetary policy decisions of the central bank of nigeria affect you - The money supply effect", Monetary policy series, monetary policy dept.

- CBN Statistical Bulletins( 2017 and 2018)

- Eze, R., \& Nwankwo, O. (2012). Electronic Payment in Cashless Economy of Nigeria: Problems and Prospect. International Research Journal of Finance and Economics, December(170). Crossref

- Ikpefan, O. A., Akpan, E., Osuma, G. O., Evbuomwan, G., \& Ndigwe, C. (2018). Electronic Banking and Cashless Policy in Nigeria. International Journal of Civil Engineering and Technology (IJCIET), 9(10), 718-731. Retrieved from 
Kanu Success Ikechi, Eke Karen Chinonso, Nwadiubu, Anthony, Ikechukwu Robert Eze The Use of E-payment Products and their Impact on Currency-in-Circulation in Nigeria

http://www.iaeme.com/IJCIET/index.asp718http://www.iaeme.com/ijciet/issues.asp?JType $=$ IJCIET\&VType $=9 \& I T y p e=10 \mathrm{http}: / / \mathrm{www} \cdot$ iaeme $\cdot$ comhttp $: / / \mathrm{www} \cdot$ iaeme.com/IJCIET/issues. asp? JType $=$ IJCIET\&VType $=9 \& I T y p e=10$

- Okifo, J., \& Igbunu, R. (2015). Electronic Payment System in Nigeria: Its Economic Benefits and Challenges. Journal of Education and Practice, 6(16), 56-63.

- Paul, E. (2019). CBN wants you to go cashless but still spends billions annually printing cash. Retrieved March 28, 2020, from https://techpoint. africa/2019/10/17/cbn-cashless-printingcash/

- Papadopoulos. G. (2007); Electronic money and the possibility of a cashless society Working Paper 18.02.2007, Retrieved from https: //www.research gate.net/publication Crossref

- Patrick G. (2017); cash is still king in the digital era; CNN Money (New York)

- Popovska- Kamnar, N. (2014): The use of electronic money and its impact on monetary policy, Journal of Contemporary Economic and Business Issues, ISSN 1857-9108, Ss. Cyril and Methodius University in Skopje, Faculty of Economics, Skopje, Vol. 1, Iss. 2, pp. 79-92. 